\title{
Alphaherpesvirus Subversion of Stress-Induced Translational Arrest
}

\author{
Renée L. Finnen and Bruce W. Banfield * \\ Department of Biomedical and Molecular Sciences, Queen's University, Kingston, ON K7L 3N6, Canada; \\ renee.finnen@queensu.ca \\ * Correspondence: bruce.banfield@queensu.ca; Tel.: +1-613-533-2459
}

Academic Editor: Craig McCormick

Received: 21 January 2016; Accepted: 2 March 2016; Published: 15 March 2016

\begin{abstract}
In this article, we provide an overview of translational arrest in eukaryotic cells in response to stress and the tactics used specifically by alphaherpesviruses to overcome translational arrest. One consequence of translational arrest is the formation of cytoplasmic compartments called stress granules (SGs). Many viruses target SGs for disruption and/or modification, including the alphaherpesvirus herpes simplex virus type 2 (HSV-2). Recently, it was discovered that HSV-2 disrupts SG formation early after infection via virion host shutoff protein (vhs), an endoribonuclease that is packaged within the HSV-2 virion. We review this discovery and discuss the insights it has provided into SG biology as well as its potential significance in HSV-2 infection. A model for vhs-mediated disruption of SG formation is presented.
\end{abstract}

Keywords: alphaherpesvirus; translational arrest; stress granules

\section{Translational Arrest in Response to Stress}

Cellular responses to stressful stimuli can be broadly categorized as destructive, resulting in cell death or protective, resulting in cell survival. The general shutdown and reprogramming of translation that occurs in cells in response to stress can be considered protective: by stopping the synthesis of most proteins, cellular resources are thereby conserved and can, instead, be focused on synthesizing those proteins required for surviving the stress.

Regulation of cap-dependent translation occurs primarily at the level of initiation, though recent evidence suggests that regulation can also occur at the level of elongation [1]. Assembly of both of the macromolecular complexes required for translation initiation, the $43 \mathrm{~S}$ ribosomal pre-initiation complex (43S PIC) and the eIF4F cap-binding complex, can be targeted to shut down translation. The $43 \mathrm{~S}$ PIC is targeted through the activation of eukaryotic initiation factor 2 (eIF2) kinases. Eukaryotic cells employ four eIF2 kinases to sense stressful conditions in their environment [2]. The stressors that eIF2 kinases can sense include environmental changes like elevated temperature (heat shock), accumulation of misfolded proteins, starvation and oxidation. In addition to sensing environmental stress, the double-stranded RNA (dsRNA)-dependent protein kinase (PKR) can sense the presence of viruses. Following the sensing of environmental stress or viral infection, eIF2 kinases become activated and phosphorylate the alpha subunit of eIF2 (eIF2 $\alpha)$, ultimately leading to a failure to assemble the 43S PIC [3-6]. Many different stressors result in reduced activity of the mechanistic target of rapamycin (mTOR) kinase. Two components of eIF4F, the cap-binding protein eIF4E and the RNA helicase eIF4A, are affected by independent mechanisms stemming from reduced activity of the mTOR complex 1 (mTORC1), resulting in reduced assembly and functionality of eIF4F [3-6].

Subsets of cellular mRNAs continue to be selectively translated when cap-dependent translation is shut down. Many of these mRNAs encode stress response proteins that facilitate survival and recovery such as chaperones [7,8], repair enzymes [9], and apoptosis inhibitors [10-12] as well as 
transcriptional activators of stress response genes [13,14]. Initiation of translation on these mRNAs proceeds by cap-independent mechanisms. The best-characterized of these mechanisms is the use of internal ribosome entry sites (IRESs), complex structural elements found in the $5^{\prime}$ untranslated regions (5' UTRs) of mRNAs. First identified in poliovirus [15,16], IRESs directly recruit ribosomes without the requirement for some or even all initiation factors [17,18]. With the advent of recent technologies such as ribosome profiling [19], we stand poised to discover more details about these cap-independent translation mechanisms as well as the breadth of translational reprogramming in eukaryotic cells during times of stress.

\section{Alphaherpesvirus Subversion of Translational Arrest}

Stoppages in protein synthesis are problematic for all viruses because they rely on the host cell's translation machinery for the production of their proteins. Thus viruses must counteract the strategies used by cells to inhibit translation initiation or employ non-canonical modes of translation initiation to facilitate continued protein synthesis and promote their replication. The wide variety of tactics used by viruses to ensure synthesis of their proteins has been comprehensively reviewed by Walsh et al. [18]. The tactics specifically used by the alphaherpesviruses, the main subject of this article, have primarily been studied in herpes simplex virus type 1 (HSV-1). HSV-1 utilizes four proteins to counteract activation of eIF2 kinases and the resulting phosphorylation of eIF2 $\alpha$ : Us11 blocks PKR activation by binding dsRNA [20,21]; vhs blocks PKR activation via its endoribonuclease activity [22]; glycoprotein B (gB) blocks the ability of the PKR related endoplasmic reticulum kinase (PERK) to sense protein misfolding in the endoplasmic reticulum by binding the luminal domain of PERK [23]; and ICP34.5 recruits cellular protein phosphatase 1a to dephosphorylate eIF2 $\alpha$ [24]. These viral proteins carry out their antagonistic roles at different times during infection from the immediate onset of viral infection (vhs) to early after viral DNA synthesis (ICP34.5) to late in the infection (gB and Us11) allowing HSV-1 to continuously counteract eIF2 kinase activation [22]. Other alphaherpesviruses, such as varicella zoster virus (VZV) and pseudorabies virus (PRV), do not encode homologues of Us11 or ICP34.5 and use additional viral proteins to prevent phosphorylation of eIF2 $\alpha$. The VZV virion component ORF63 and the PRV immediate early protein IE180 have both been implicated in the suppression of eIF2 $\alpha$ phosphorylation $[25,26]$. To ensure the assembly of eIF4F, the HSV-1 serine/threonine kinase, Us3, promotes the constitutive activation of mTORC1 [27], the immediate early protein, ICP0, promotes the incorporation of eIF4E into eIF4F [28] and the chaperone-like activity of ICP6 promotes the interaction of eIF4F components eIF4E and eIF4G [29]. In addition to these counteractive tactics, non-canonical mechanisms are used for the translation of some alphaherpesvirus mRNAs. IRES-mediated translation has been described for HSV-1 thymidine kinase [30] and for Marek's disease virus RLORF9 protein [31-33]. Although vhs is most often described as an endoribonuclease, there is evidence that it can also play a role as a translational modulator [34,35]. In this role, vhs can enhance cap-independent translation of mRNAs via cis-acting elements in their 5' UTRs including cellular mRNAs known to contain an IRES as well as viral mRNAs encoding thymidine kinase, UL12 and gC [35]. Moreover, the ability of some of these cis-acting elements to direct translation can be strictly vhs-dependent.

\section{Stress Granule Formation as a Consequence of Translational Arrest}

A consequence of stoppages in protein synthesis is the formation of non-membrane bound cytoplasmic compartments known as stress granules (SGs). SGs are primarily composed of translationally silent $\mathrm{mRNAs}$ that remain associated with a cadre of translation initiation proteins, poly(A)-binding protein (PABP) and the small ribosomal subunit in the form of messenger ribonucleoprotein complexes (mRNPs) [36-38]. SGs can be quite irregular in shape and variable in size, ranging from 0.1 to $2 \mu \mathrm{m}$ in diameter [39]. While their protein composition can also be variable, core mRNP components serve as definitive markers of SGs and certain cellular mRNA binding proteins, 
such as Ras-GTPase-activating SH3-domain-binding proteins (G3BP-1 and G3BP-2) and T cell internal antigen 1 (TIA-1), can also serve as reliable markers of these compartments [37].

SGs form rapidly in response to stress-induced phosphorylation of eIF $2 \alpha$ or in response to compounds that stop protein synthesis by means that are mechanistically distinct from eIF $2 \alpha$ phosphorylation, such as puromycin and pateamine A (PatA) [40-42]. Conversely, compounds that keep mRNAs associated with 80 S ribosomes, such as cycloheximide and emetine, discourage SG formation [42]. These observations have led to a SG assembly model whereby the sudden increase in cytoplasmic levels of free mRNPs that follows stoppages in protein synthesis is the seminal event that initiates SG assembly [37]. The requirement for RNA in SG assembly is supported by the recent studies of Pastré and colleagues, who demonstrated that delivery of exogenous single stranded nucleic acid (RNA or DNA) to cells could promote SG assembly [43], and by the recent in vitro studies of Cech and colleagues, who demonstrated that the formation of higher-order assemblages of the RNA binding protein Fused in Sarcoma (FUS) could be seeded by the addition of RNA [44].

The steps leading from an increase in cytoplasmic levels of free mRNPs through to the assembly of microscopically visible cytoplasmic granules are ill-defined. The involvement of cellular proteins with both RNA binding capacity and prion like domains, such as G3BP and TIA-1, in SG assembly is well established $[45,46]$ implicating the importance of RNA-protein and protein-protein interactions in assembling these structures. For G3BP in particular, SG assembly is inhibited by cleavage of G3BP-1 [47] or by disruption of ability of either G3BP-1 or G3BP-2 to bind other SG proteins [48]. Many post-translational modifications to SG proteins have also been implicated in SG assembly including dephosphorylation [46], methylation [49,50], deacetylation [51], ubiquitination [51], O-GlcNac modification [52] and poly(ADP ribosyl)ation (PARylation) [53-55]. Weak intermolecular interactions facilitated by RNA binding proteins with prion like domains in combination with these various post-translational modifications has been proposed by Alberti and colleagues to allow mammalian SGs to exist in a liquid droplet-like state that facilitates trafficking of components into and out of SGs [56]. Finally, interactions between mRNPs and the cytoskeleton are also required for SG assembly [57-61]. The conventional model of SG assembly along with the physical state in which SGs exist have been challenged by very recent work published by Parker and colleagues [62]. Their analysis of SGs using super-resolution microscopy suggested that SGs have a stable core structure surrounded by a more dynamic shell. Moreover, their success in purifying and determining the protein composition of these SG cores has important implications for the field. Like SG assembly, SG disassembly can proceed rapidly and is mechanistically ill-defined. Reversal of some of the post-translational modifications implicated in SG assembly can cause SG disassembly. For example, phosphorylation of SG proteins G3BP [46], growth factor receptor-bound protein 7 (Grb7; [63]) and dual specificity tyrosine-phosphorylation-regulated kinase 3 (DYRK3; [64]) all lead to SG disassembly, as does removal of PAR modifications by PAR glycohydrolases [55].

The primary role postulated for SGs is for temporary storage of cellular mRNAs during periods of stress $[37,65]$. As these mRNAs remain associated with components of the translation machinery, protein synthesis can resume quickly once the stress subsides and SGs are disassembled, thus helping the cell survive the period of stress. However, recent studies by Huttelmaier and colleagues provide evidence that mRNA translation and stabilization is largely independent of SG formation [66], suggesting that SGs likely play additional roles to enable stress survival. One new role that is particularly pertinent to viral infection is to promote innate immune responses. Fujita and colleagues demonstrated that two cellular sensors of viral RNA that trigger innate immune responses, PKR and retinoic acid inducible gene I (RIG-I), both localize to SGs that are induced following viral infection [67,68]. Several proteins involved in regulating RIG-I also localize to SGs [69-71]. Furthermore, Lloyd and colleagues have described SG-specific activation of PKR. According to their model, SG proteins G3BP-1 and caprin-1 form a complex with inactive PKR in the cytoplasm and, following the induction of stress, this complex is recruited into SGs where PKR becomes activated in a manner that is independent of foreign dsRNA recognition [72,73]. Activated PKR is subsequently 
released from SGs where it can proceed to shut down translation as well as trigger other PKR-mediated responses [74-77]. These links between SG formation and innate immune responses have led to the proposal that SGs serve as platforms for recognizing and responding to viral infections [70], which may explain why so many viruses destroy or modify these cytoplasmic compartments during infection (for overviews of the impact of various viruses on SGs, see references [70,78-81]). By understanding how viruses manipulate SGs, we stand not only to learn more about virus/host interactions but also to gain insights into the incompletely understood cycle of SG assembly and disassembly. As aberrant SG formation is a feature associated with several neurodegenerative diseases in humans [82-85], these insights may prove valuable for understanding and treating these diseases.

\section{HSV-2 Infection Differentially Impacts Stress Granule Formation}

The importance of SG formation in suppressing HSV infection was suggested by the enhanced growth of HSV-1 in cells in which production of the SG component TIA-1 or the related protein, TIAR, had been knocked out [86]. Infection of cells by HSV activates at least two eIF2 kinases, and yet accumulation of SGs is not observed following infection by HSV-1 strains F and KOS $[87,88]$ or by HSV-2 strains HG52, G and $186[89,90]$. While these observations may be reflective of the combined abilities of Us11, vhs, gB and ICP34.5 to counteract the activities of PKR and PERK, they may be indicative of a direct impact of HSV infection on SG formation. When we investigated the ability of cells infected with HSV-2 to form SGs following arsenite treatment to induce oxidative stress [91], we discovered that infected cells had a disruption in their ability to form SGs in response to the arsenite treatment [90]. HSV-2-infected cells maintained the ability to phosphorylate eIF $2 \alpha$ in response to the arsenite treatment indicating that, mechanistically, this disruption occurs downstream of eIF $2 \alpha$ phosphorylation. Consistent with a block to SG formation occurring irrespective of the phosphorylation status of eIF $2 \alpha$, we observed that HSV-2 infected cells also have a disruption in their ability to form SGs in response to PatA. PatA disrupts translation initiation in an eIF2 $\alpha$-independent manner by irreversibly binding to eIF4A and modulating its activity [5,40,41]. In our initial SG disruption analyses, we followed TIA-1 as a marker of SGs. In subsequent assays using antibodies against G3BP to follow SG formation, we observed that G3BP positive SGs remained in infected cells following PatA treatment, however, these remaining SGs were largely devoid of TIA-1 [90]. This contrasted the situation in infected cells treated with arsenite where SGs were not detectable using either marker.

The differential impact of HSV-2 infection on SGs induced by arsenite versus those induced by PatA may arise as a result of fundamental differences in the properties of SGs induced by different mechanisms. PatA-induced SGs can persist for as long as $12 \mathrm{~h}$ post-treatment [92] whereas arsenite-induced SGs are much more rapidly disassembled [38]. If PatA-induced SGs are inherently more stable than their arsenite-induced counterparts, their disassembly as a consequence of HSV-2 infection may proceed with different kinetics or with a different order of departure of SG components allowing G3BP positive, TIA-1 negative SGs to remain in infected cells following PatA treatment. Alternatively, if the requirement for TIA-1 in assembling arsenite-induced SGs is more stringent than for PatA-induced SGs, viral modulation of TIA-1 may result in greater inhibition of SG formation in response to arsenite treatment as compared to PatA treatment. We have, in fact, observed an effect on TIA-1 localization following HSV-2 infection. At late times post-infection, TIA-1 localizes to novel nuclear structures that contain the RNA binding protein 68-kDa Src-associated in mitosis (Sam68; [90]). Understanding the differential impact of HSV-2 infection on SG formation will hinge on establishing whether the disruption in SG formation observed in HSV-2 infected cells occurs as a result of promotion of SG disassembly or prevention of SG assembly or as a result of both of these activities. We noted in our initial studies on the impact of HSV-2 on SG formation that the number of cells containing SGs as a result of over expression of GFP-TIA-1 was noticeably diminished when these cells were subsequently infected [90]. These results imply that disassembly of preformed SGs may be enhanced in the presence of HSV-2. We are currently developing more rigorous assays for determining whether HSV-2 infection can promote the disruption of preformed SGs. 


\section{HSV-2 vhs Interferes with Stress Granule Formation}

An obvious question stemming from our discovery that HSV-2 infection disrupted arsenite-induced SG formation was which viral protein(s) was responsible for this activity. We demonstrated that disruption of arsenite-induced SG formation in infected cells was detectable as early as $30 \mathrm{~min}$ post infection [89] and occurred in the absence of both viral DNA replication [90] and viral gene transcription [89]. In addition, disruption of arsenite-induced SG formation was not detected when virions were removed from the inoculum [90]. These observations indicated that this disruption could be mediated by a virion component. Two independent research groups had previously reported that spontaneous SGs form late in infection in cells infected with vhs-defective strains of HSV-1 $[87,88]$. This connection between vhs and SGs coupled with the well-established fact that vhs is a component of the alphaherpesvirus virion [93-95] made vhs a likely candidate to mediate this disruption. We demonstrated that cells infected with HSV-2 strains carrying defects in vhs were defective in their ability to disrupt arsenite-induced SG formation and that this ability was restored when a defect in vhs was specifically repaired [89]. Furthermore, disruption of arsenite-induced SG formation was observed in cells transfected with vhs expression constructs, indicating that vhs could mediate this disruption in the absence of other viral proteins.

vhs is an endoribonuclease [96-99] encoded by the UL41 gene [100,101]. Packaging of vhs into virions allows this endoribonuclease to be delivered to the cytoplasm immediately upon fusion of viral and cellular membranes and to commence the degradation of cellular mRNAs in advance of de novo viral gene expression. Cleavage of most mRNAs by vhs in vivo occurs within the $5^{\prime}$ UTR near the cap and the resulting decapped mRNAs are then rapidly degraded by the cellular $5^{\prime}-3^{\prime}$ exonuclease Xrn1 $[102,103]$. Targeting of vhs endoribonuclease activity towards mRNAs in vivo may be facilitated by its ability to bind the cellular translation initiation factors eIF4A, eIF4B and eIF4H [104,105]. The ability of vhs to bind to translation initiation factors may also be indicative of a direct role for vhs in translation. This notion is supported by the studies of Smiley and colleagues who demonstrated that vhs activates cap-independent translation via cis-acting elements and also enhances the translation of viral late mRNAs $[34,35,87,106]$. As vhs may interact with mRNA in two distinct manners and has the ability to bind eIF4A, eIF4B, and eIF4H, all of which are known SG components [107], predicting which vhs activity is required to disrupt $S G$ formation is not entirely straightforward. However, given that free mRNP is a key ingredient in SG assembly [43], the simplest model of how vhs disrupts SG formation, depicted in the lower portion of Figure 1, is that destruction of mRNA (as a component of polysomes, free mRNPs or submicroscopic coalesced mRNPs) by the combination of vhs endoribonuclease and Xrn1 exonuclease activities prevents SGs from assembling into microscopically visible structures. Alternatively or additionally, destruction of the mRNA contained within microscopically visible SGs by vhs and Xrn1 could drive the disassembly of these structures. In this mode, vhs can be considered a SG disaggregase. If vhs endoribonuclease activity is required for it to function as a SG disaggregase, it follows that maintaining intact mRNA is crucial for maintaining SG integrity. It also follows that both vhs and Xrn1 should be able to localize to SGs. We have observed localization of vhs at SGs induced in HeLa cells transfected with an endoribonuclease deficient vhs construct suggesting that vhs has this ability [108]. While Xrn1 is often described as a marker of processing bodies, another type of cytoplasmic RNA granule often found associated with SGs, small amounts of Xrn1 have been found to localize to SGs [109]. Our future studies will take advantage of the wealth of knowledge about functional domains and residues within vhs $[105,110,111]$ to define which activities contribute to disruption of SG formation and to distinguish between the two possible modes of vhs-mediated disruption of SG formation depicted in Figure 1. 


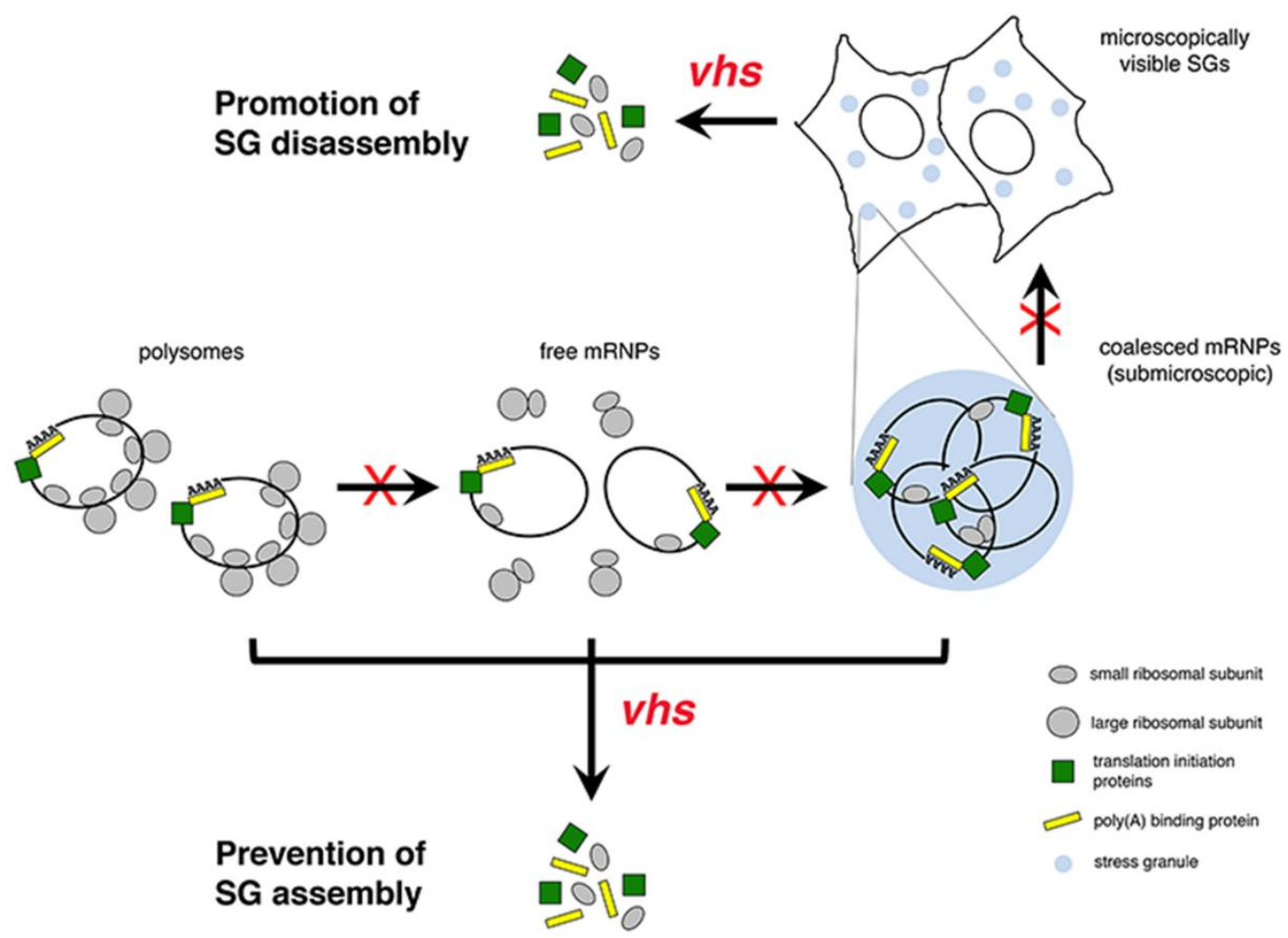

Figure 1. Model of virion host shutoff protein (vhs) endoribonuclease-mediated disruption of stress granule (SG) formation. Two different modes of disruption by vhs are proposed. vhs endoribonuclease activity promotes the destruction of mRNAs present in existing SGs leading to their disassembly. Alternatively or additionally, vhs endoribonuclease activity promotes the destruction of mRNAs present in polysomes, free messenger ribonucleoproteins (mRNPs) or submicroscopic coalesced mRNPs preventing the ensuing step in the SG assembly pathway. For simplicity, microscopically visible SGs as well as submicroscopic coalesced mRNPs that serve as SG nucleation sites are both represented as blue circles; microscopically visible SGs are often irregular in shape and are variable in size.

\section{Significance of vhs-Mediated Disruption of Stress Granule Formation}

The recent work connecting SGs with innate immune responses $[67,70,72,73]$ has reinforced the view of SGs as antiviral in nature. We have demonstrated that vhs-mediated disruption of SG formation can be detected as early as 30 min after infection [89], a timeframe consistent with counteraction of an early antiviral response involving SGs. We propose that vhs-mediated promotion of SG disassembly and/or prevention of SG assembly counteracts SG-specific activation of innate immune responses. Lloyd and colleagues have speculated that SG-specific activation of PKR may arise from interplay between G3BP-1 and caprin-1 without requiring RNA ligands [72]. If SG-specific activation of PKR were truly independent of RNA ligands, vhs disruption of this mode of PKR activation would differ from the model of vhs-mediated PKR inactivation described by Roizman and colleagues. This model proposes that vhs-mediated inhibition of PKR arises as a result of clearance of self-annealing RNAs that carry double-stranded stretches capable of activating PKR [22]. Counteraction of SG-specific activation of innate immune responses may be an evasion strategy shared by other viruses that encode an endonuclease known to be involved in restricting host gene expression such as the gammaherpesviruses Kaposi's sarcoma-associated herpesvirus (SOX; [112,113]), murine gammaherpesvirus 68 (muSOX; [114]), and Epstein-Barr virus (BGLF5; [115]) as well as influenza A virus (PA-X; $[92,116])$. 
Acknowledgments: Work in the Banfield laboratory is supported by Canadian Institutes of Health Research operating grant 93804, Natural Sciences and Engineering Council of Canada Discovery Grant 418719 and Canada Foundation for Innovation award 16389. We apologize to colleagues whose work could not be cited because of length restrictions.

Author Contributions: R.L. Finnen and B.W. Banfield wrote the paper.

Conflicts of Interest: The authors declare no conflict of interest.

\section{References}

1. Shalgi, R.; Hurt, J.A.; Krykbaeva, I.; Taipale, M.; Lindquist, S.; Burge, C.B. Widespread regulation of translation by elongation pausing in heat shock. Mol. Cell. 2013, 49, 439-452. [CrossRef] [PubMed]

2. Wek, R.C.; Jiang, H.Y.; Anthony, T.G. Coping with stress: EiF2 kinases and translational control. Biochem. Soc. Trans. 2006, 34, 7-11. [CrossRef] [PubMed]

3. Hershey, J.W.; Sonenberg, N.; Mathews, M.B. Principles of translational control: An overview. Cold Spring Harb. Perspect. Biol. 2012, 4. [CrossRef] [PubMed]

4. Hinnebusch, A.G.; Lorsch, J.R. The mechanism of eukaryotic translation initiation: New insights and challenges. Cold Spring Harb. Perspect. Biol. 2012, 4. [CrossRef] [PubMed]

5. Parsyan, A.; Svitkin, Y.; Shahbazian, D.; Gkogkas, C.; Lasko, P.; Merrick, W.C.; Sonenberg, N. mRNA helicases: The tacticians of translational control. Nat. Rev. Mol. Cell Biol. 2011, 12, 235-245. [CrossRef] [PubMed]

6. Spriggs, K.A.; Bushell, M.; Willis, A.E. Translational regulation of gene expression during conditions of cell stress. Mol. Cell 2010, 40, 228-237. [CrossRef] [PubMed]

7. Macejak, D.G.; Sarnow, P. Internal initiation of translation mediated by the $5^{\prime}$ leader of a cellular mRNA. Nature 1991, 353, 90-94. [CrossRef] [PubMed]

8. Carper, S.W.; Rocheleau, T.A.; Cimino, D.; Storm, F.K. Heat shock protein 27 stimulates recovery of RNA and protein synthesis following a heat shock. J. Cell. Biochem. 1997, 66, 153-164. [CrossRef]

9. Powley, I.R.; Kondrashov, A.; Young, L.A.; Dobbyn, H.C.; Hill, K.; Cannell, I.G.; Stoneley, M.; Kong, Y.W.; Cotes, J.A.; Smith, G.C.; et al. Translational reprogramming following UVB irradiation is mediated by DNA-PKcs and allows selective recruitment to the polysomes of mRNAs encoding DNA repair enzymes. Genes Dev. 2009, 23, 1207-1220. [CrossRef] [PubMed]

10. Warnakulasuriyarachchi, D.; Cerquozzi, S.; Cheung, H.H.; Holcik, M. Translational induction of the inhibitor of apoptosis protein HIAP2 during endoplasmic reticulum stress attenuates cell death and is mediated via an inducible internal ribosome entry site element. J. Biol. Chem. 2004, 279, 17148-17157. [CrossRef] [PubMed]

11. Coldwell, M.J.; deSchoolmeester, M.L.; Fraser, G.A.; Pickering, B.M.; Packham, G.; Willis, A.E. The p36 isoform of BAG-1 is translated by internal ribosome entry following heat shock. Oncogene 2001, 20, 4095-4100. [CrossRef] [PubMed]

12. Sherrill, K.W.; Byrd, M.P.; Van Eden, M.E.; Lloyd, R.E. Bcl-2 translation is mediated via internal ribosome entry during cell stress. J. Biol. Chem. 2004, 279, 29066-29074. [CrossRef] [PubMed]

13. Blais, J.D.; Filipenko, V.; Bi, M.; Harding, H.P.; Ron, D.; Koumenis, C.; Wouters, B.G.; Bell, J.C. Activating transcription factor 4 is translationally regulated by hypoxic stress. Mol. Cell. Biol. 2004, 24, 7469-7482. [CrossRef] [PubMed]

14. Lang, K.J.; Kappel, A.; Goodall, G.J. Hypoxia-inducible factor-1alpha mRNA contains an internal ribosome entry site that allows efficient translation during normoxia and hypoxia. Mol. Biol. Cell 2002, 13, 1792-1801. [CrossRef] [PubMed]

15. Pelletier, J.; Sonenberg, N. Internal initiation of translation of eukaryotic mRNA directed by a sequence derived from poliovirus RNA. Nature 1988, 334, 320-325. [CrossRef] [PubMed]

16. Trono, D.; Pelletier, J.; Sonenberg, N.; Baltimore, D. Translation in mammalian cells of a gene linked to the poliovirus $5^{\prime}$ noncoding region. Science 1988, 241, 445-448. [CrossRef] [PubMed]

17. Liu, B.; Qian, S.B. Translational reprogramming in cellular stress response. Wiley Interdiscip. Rev. RNA 2014, 5, 301-315. [CrossRef] [PubMed]

18. Walsh, D.; Mathews, M.B.; Mohr, I. Tinkering with translation: Protein synthesis in virus-infected cells. Cold Spring Harb. Perspect. Biol. 2013, 5, a012351. [CrossRef] [PubMed] 
19. Ingolia, N.T.; Ghaemmaghami, S.; Newman, J.R.; Weissman, J.S. Genome-wide analysis in vivo of translation with nucleotide resolution using ribosome profiling. Science 2009, 324, 218-223. [CrossRef] [PubMed]

20. Cassady, K.A.; Gross, M. The herpes simplex virus type $1 \mathrm{u}(\mathrm{s}) 11$ protein interacts with protein kinase R in infected cells and requires a 30-amino-acid sequence adjacent to a kinase substrate domain. J. Virol. 2002, 76, 2029-2035. [CrossRef] [PubMed]

21. Cassady, K.A.; Gross, M.; Roizman, B. The herpes simplex virus US11 protein effectively compensates for the gamma1(34.5) gene if present before activation of protein kinase $\mathrm{R}$ by precluding its phosphorylation and that of the alpha subunit of eukaryotic translation initiation factor 2. J. Virol. 1998, 72, 8620-8626. [PubMed]

22. Sciortino, M.T.; Parisi, T.; Siracusano, G.; Mastino, A.; Taddeo, B.; Roizman, B. The virion host shutoff RNase plays a key role in blocking the activation of protein kinase $\mathrm{R}$ in cells infected with herpes simplex virus 1. J. Virol. 2013, 87, 3271-3276. [CrossRef] [PubMed]

23. Mulvey, M.; Arias, C.; Mohr, I. Maintenance of endoplasmic reticulum (ER) homeostasis in herpes simplex virus type 1-infected cells through the association of a viral glycoprotein with PERK, a cellular ER stress sensor. J. Virol. 2007, 81, 3377-3390. [CrossRef] [PubMed]

24. He, B.; Gross, M.; Roizman, B. The gamma(1)34.5 protein of herpes simplex virus 1 complexes with protein phosphatase 1alpha to dephosphorylate the alpha subunit of the eukaryotic translation initiation factor 2 and preclude the shutoff of protein synthesis by double-stranded RNA-activated protein kinase. Proc. Natl. Acad. Sci. USA 1997, 94, 843-848. [PubMed]

25. Van Opdenbosch, N.; Van den Broeke, C.; De Regge, N.; Tabares, E.; Favoreel, H.W. The IE180 protein of pseudorabies virus suppresses phosphorylation of translation initiation factor eIF2alpha. J. Virol. 2012, 86, 7235-7240. [CrossRef] [PubMed]

26. Ambagala, A.P.; Cohen, J.I. Varicella-zoster virus IE63, a major viral latency protein, is required to inhibit the alpha interferon-induced antiviral response. J. Virol. 2007, 81, 7844-7851. [CrossRef] [PubMed]

27. Chuluunbaatar, U.; Roller, R.; Feldman, M.E.; Brown, S.; Shokat, K.M.; Mohr, I. Constitutive mTORC1 activation by a herpesvirus AKT surrogate stimulates mRNA translation and viral replication. Genes Dev. 2010, 24, 2627-2639. [CrossRef] [PubMed]

28. Walsh, D.; Mohr, I. Phosphorylation of eIF4E by MNK-1 enhances hsv-1 translation and replication in quiescent cells. Genes Dev. 2004, 18, 660-672. [CrossRef] [PubMed]

29. Walsh, D.; Mohr, I. Assembly of an active translation initiation factor complex by a viral protein. Genes Dev. 2006, 20, 461-472. [CrossRef] [PubMed]

30. Griffiths, A.; Coen, D.M. An unusual internal ribosome entry site in the herpes simplex virus thymidine kinase gene. Proc. Natl. Acad. Sci. USA 2005, 102, 9667-9672. [CrossRef] [PubMed]

31. Tahiri-Alaoui, A.; Matsuda, D.; Xu, H.; Panagiotis, P.; Burman, L.; Lambeth, L.S.; Petherbridge, L.; James, W.; Mauro, V.; Nair, V. The $5^{\prime}$ leader of the mRNA encoding the marek's disease virus serotype 1 PP14 protein contains an intronic internal ribosome entry site with allosteric properties. J. Virol. 2009, 83, 12769-12778. [PubMed]

32. Tahiri-Alaoui, A.; Smith, L.P.; Baigent, S.; Kgosana, L.; Petherbridge, L.J.; Lambeth, L.S.; James, W.; Nair, V. Identification of an intercistronic internal ribosome entry site in a marek's disease virus immediate-early gene. J. Virol. 2009, 83, 5846-5853. [CrossRef] [PubMed]

33. Tahiri-Alaoui, A.; Zhao, Y.; Sadigh, Y.; Popplestone, J.; Kgosana, L.; Smith, L.P.; Nair, V. Poly(A) binding protein 1 enhances cap-independent translation initiation of neurovirulence factor from avian herpesvirus. PLOS ONE 2014, 9, e114466.

34. Elgadi, M.M.; Smiley, J.R. Picornavirus internal ribosome entry site elements target RNA cleavage events induced by the herpes simplex virus virion host shutoff protein. J. Virol. 1999, 73, 9222-9231. [PubMed]

35. Saffran, H.A.; Read, G.S.; Smiley, J.R. Evidence for translational regulation by the herpes simplex virus virion host shutoff protein. J. Virol. 2010, 84, 6041-6049. [CrossRef] [PubMed]

36. Souquere, S.; Mollet, S.; Kress, M.; Dautry, F.; Pierron, G.; Weil, D. Unravelling the ultrastructure of stress granules and associated P-bodies in human cells. J. Cell Sci. 2009, 122, 3619-3626. [CrossRef] [PubMed]

37. Anderson, P.; Kedersha, N. Stress granules: The tao of rna triage. Trends Biochem. Sci. 2008, 33, 141-150. [CrossRef] [PubMed]

38. Kedersha, N.; Chen, S.; Gilks, N.; Li, W.; Miller, I.J.; Stahl, J.; Anderson, P. Evidence that ternary complex (eIF2-GTP-tRNA(i)(met))-deficient preinitiation complexes are core constituents of mammalian stress granules. Mol. Biol. Cell 2002, 13, 195-210. [CrossRef] [PubMed] 
39. Anderson, P.; Kedersha, N. Stress granules. Curr. Biol. 2009, 19, R397-R398. [CrossRef] [PubMed]

40. Mazroui, R.; Sukarieh, R.; Bordeleau, M.E.; Kaufman, R.J.; Northcote, P.; Tanaka, J.; Gallouzi, I.; Pelletier, J. Inhibition of ribosome recruitment induces stress granule formation independently of eukaryotic initiation factor 2alpha phosphorylation. Mol. Biol. Cell 2006, 17, 4212-4219. [CrossRef] [PubMed]

41. Dang, Y.; Kedersha, N.; Low, W.K.; Romo, D.; Gorospe, M.; Kaufman, R.; Anderson, P.; Liu, J.O. Eukaryotic initiation factor 2alpha-independent pathway of stress granule induction by the natural product pateamine $\mathrm{A}$. J. Biol. Chem. 2006, 281, 32870-32878. [CrossRef] [PubMed]

42. Kedersha, N.; Cho, M.R.; Li, W.; Yacono, P.W.; Chen, S.; Gilks, N.; Golan, D.E.; Anderson, P. Dynamic shuttling of TIA-1 accompanies the recruitment of mRNA to mammalian stress granules. J. Cell Biol. 2000, 151, 1257-1268. [CrossRef] [PubMed]

43. Bounedjah, O.; Desforges, B.; Wu, T.D.; Pioche-Durieu, C.; Marco, S.; Hamon, L.; Curmi, P.A.; Guerquin-Kern, J.L.; Pietrement, O.; Pastre, D. Free mRNA in excess upon polysome dissociation is a scaffold for protein multimerization to form stress granules. Nucleic Acids Res. 2014, 42, 8678-8691. [CrossRef] [PubMed]

44. Schwartz, J.C.; Wang, X.; Podell, E.R.; Cech, T.R. RNA seeds higher-order assembly of FUS protein. Cell Rep. 2013, 5, 918-925. [CrossRef] [PubMed]

45. Gilks, N.; Kedersha, N.; Ayodele, M.; Shen, L.; Stoecklin, G.; Dember, L.M.; Anderson, P. Stress granule assembly is mediated by prion-like aggregation of TIA-1. Mol. Biol. Cell 2004, 15, 5383-5398. [CrossRef] [PubMed]

46. Tourriere, H.; Chebli, K.; Zekri, L.; Courselaud, B.; Blanchard, J.M.; Bertrand, E.; Tazi, J. The RasGAP-associated endoribonuclease G3BP assembles stress granules. J. Cell Biol. 2003, 160, 823-831. [CrossRef] [PubMed]

47. White, J.P.; Cardenas, A.M.; Marissen, W.E.; Lloyd, R.E. Inhibition of cytoplasmic mRNA stress granule formation by a viral proteinase. Cell Host Microbe 2007, 2, 295-305. [CrossRef] [PubMed]

48. Panas, M.D.; Schulte, T.; Thaa, B.; Sandalova, T.; Kedersha, N.; Achour, A.; McInerney, G.M. Viral and cellular proteins containing FGDF motifs bind G3BP to block stress granule formation. PLoS Pathog. 2015, 11, e1004659. [CrossRef] [PubMed]

49. Dolzhanskaya, N.; Merz, G.; Aletta, J.M.; Denman, R.B. Methylation regulates the intracellular protein-protein and protein-RNA interactions of FMRP. J. Cell Sci. 2006, 119, 1933-1946. [CrossRef] [PubMed]

50. De Leeuw, F.; Zhang, T.; Wauquier, C.; Huez, G.; Kruys, V.; Gueydan, C. The cold-inducible RNA-binding protein migrates from the nucleus to cytoplasmic stress granules by a methylation-dependent mechanism and acts as a translational repressor. Exp. Cell Res. 2007, 313, 4130-4144. [CrossRef] [PubMed]

51. Kwon, S.; Zhang, Y.; Matthias, P. The deacetylase HDAC6 is a novel critical component of stress granules involved in the stress response. Genes Dev. 2007, 21, 3381-3394. [CrossRef] [PubMed]

52. Ohn, T.; Kedersha, N.; Hickman, T.; Tisdale, S.; Anderson, P. A functional RNAi screen links o-GlcNac modification of ribosomal proteins to stress granule and processing body assembly. Nat. Cell Biol. 2008, 10, 1224-1231. [CrossRef] [PubMed]

53. Leung, A.K.; Vyas, S.; Rood, J.E.; Bhutkar, A.; Sharp, P.A.; Chang, P. Poly(ADP-ribose) regulates stress responses and microRNA activity in the cytoplasm. Mol. Cell 2011, 42, 489-499. [CrossRef] [PubMed]

54. Isabelle, M.; Gagne, J.P.; Gallouzi, I.E.; Poirier, G.G. Quantitative proteomics and dynamic imaging reveal that G3BP-mediated stress granule assembly is poly(ADP-ribose)-dependent following exposure to MNNG-induced DNA alkylation. J. Cell Sci. 2012, 125, 4555-4566. [CrossRef] [PubMed]

55. Leung, A.; Todorova, T.; Ando, Y.; Chang, P. Poly(ADP-ribose) regulates post-transcriptional gene regulation in the cytoplasm. RNA Biol. 2012, 9, 542-548. [CrossRef] [PubMed]

56. Kroschwald, S.; Maharana, S.; Mateju, D.; Malinovska, L.; Nuske, E.; Poser, I.; Richter, D.; Alberti, S. Promiscuous interactions and protein disaggregases determine the material state of stress-inducible RNP granules. eLife 2015, 4, e06807. [CrossRef] [PubMed]

57. Rajgor, D.; Shanahan, C.M. RNA granules and cytoskeletal links. Biochem. Soc. Trans. 2014, 42, 1206-1210. [CrossRef] [PubMed]

58. Ivanov, P.A.; Chudinova, E.M.; Nadezhdina, E.S. Disruption of microtubules inhibits cytoplasmic ribonucleoprotein stress granule formation. Exp. Cell Res. 2003, 290, 227-233. [CrossRef]

59. Ivanov, P.A.; Chudinova, E.M.; Nadezhdina, E.S. RNP stress-granule formation is inhibited by microtubule disruption. Cell Biol. Int. 2003, 27, 207-208. [CrossRef] 
60. Chernov, K.G.; Barbet, A.; Hamon, L.; Ovchinnikov, L.P.; Curmi, P.A.; Pastre, D. Role of microtubules in stress granule assembly: Microtubule dynamical instability favors the formation of micrometric stress granules in cells. J. Biol. Chem. 2009, 284, 36569-36580. [PubMed]

61. Loschi, M.; Leishman, C.C.; Berardone, N.; Boccaccio, G.L. Dynein and kinesin regulate stress-granule and P-body dynamics. J. Cell Sci. 2009, 122, 3973-3982. [CrossRef] [PubMed]

62. Jain, S.; Wheeler, J.R.; Walters, R.W.; Agrawal, A.; Barsic, A.; Parker, R. A TPase-modulated stress granules contain a diverse proteome and substructure. Cell 2016, 164, 487-498. [CrossRef] [PubMed]

63. Tsai, N.P.; Ho, P.C.; Wei, L.N. Regulation of stress granule dynamics by Grb7 and FAK signalling pathway. EMBO J. 2008, 27, 715-726. [CrossRef] [PubMed]

64. Wippich, F.; Bodenmiller, B.; Trajkovska, M.G.; Wanka, S.; Aebersold, R.; Pelkmans, L. Dual specificity kinase DYRK3 couples stress granule condensation/dissolution to mTORC1 signaling. Cell 2013, 152, 791-805. [CrossRef] [PubMed]

65. Decker, C.J.; Parker, R. P-bodies and stress granules: Possible roles in the control of translation and mRNA degradation. Cold Spring Harb. Perspect. Biol. 2012, 4, a012286. [CrossRef] [PubMed]

66. Bley, N.; Lederer, M.; Pfalz, B.; Reinke, C.; Fuchs, T.; Glass, M.; Moller, B.; Huttelmaier, S. Stress granules are dispensable for mRNA stabilization during cellular stress. Nucleic Acids Res. 2015, 43, e26. [CrossRef] [PubMed]

67. Onomoto, K.; Jogi, M.; Yoo, J.S.; Narita, R.; Morimoto, S.; Takemura, A.; Sambhara, S.; Kawaguchi, A.; Osari, S.; Nagata, K.; et al. Critical role of an antiviral stress granule containing RIG-i and PKR in viral detection and innate immunity. PLoS ONE 2012, 7, e43031. [CrossRef]

68. Oh, S.W.; Onomoto, K.; Wakimoto, M.; Onoguchi, K.; Ishidate, F.; Fujiwara, T.; Yoneyama, M.; Kato, H.; Fujita, T. Leader-containing uncapped viral transcript activates RIG-I in antiviral stress granules. PLoS Pathog. 2016, 12, e1005444. [CrossRef] [PubMed]

69. Kuniyoshi, K.; Takeuchi, O.; Pandey, S.; Satoh, T.; Iwasaki, H.; Akira, S.; Kawai, T. Pivotal role of RNA-binding E3 ubiquitin ligase MEX3C in RIG-I-mediated antiviral innate immunity. Proc. Natl. Acad. Sci. USA 2014, 111, 5646-5651. [CrossRef] [PubMed]

70. Onomoto, K.; Yoneyama, M.; Fung, G.; Kato, H.; Fujita, T. Antiviral innate immunity and stress granule responses. Trends Immunol. 2014, 35, 420-428. [CrossRef] [PubMed]

71. Langereis, M.A.; Feng, Q.; van Kuppeveld, F.J. MDA5 localizes to stress granules, but this localization is not required for the induction of type I interferon. J. Virol. 2013, 87, 6314-6325. [CrossRef] [PubMed]

72. Reineke, L.C.; Kedersha, N.; Langereis, M.A.; van Kuppeveld, F.J.; Lloyd, R.E. Stress granules regulate double-stranded RNA-dependent protein kinase activation through a complex containing G3BP1 and caprin-1. mBio 2015, 6, e02486. [CrossRef] [PubMed]

73. Reineke, L.C.; Lloyd, R.E. The stress granule protein G3BP1 recruits protein kinase R to promote multiple innate immune antiviral responses. J. Virol. 2015, 89, 2575-2589. [CrossRef] [PubMed]

74. Goh, K.C.; deVeer, M.J.; Williams, B.R. The protein kinase PKR is required for p38 MAPK activation and the innate immune response to bacterial endotoxin. EMBO J. 2000, 19, 4292-4297. [CrossRef] [PubMed]

75. Garcia, M.A.; Gil, J.; Ventoso, I.; Guerra, S.; Domingo, E.; Rivas, C.; Esteban, M. Impact of protein kinase PKR in cell biology: From antiviral to antiproliferative action. Microbiol. Mol. Biol. Rev. 2006, 70, 1032-1060. [CrossRef] [PubMed]

76. Nakamura, T.; Furuhashi, M.; Li, P.; Cao, H.; Tuncman, G.; Sonenberg, N.; Gorgun, C.Z.; Hotamisligil, G.S. Double-stranded RNA-dependent protein kinase links pathogen sensing with stress and metabolic homeostasis. Cell 2010, 140, 338-348. [CrossRef] [PubMed]

77. Zamanian-Daryoush, M.; Mogensen, T.H.; DiDonato, J.A.; Williams, B.R. NF-kappaB activation by double-stranded-RNA-activated protein kinase (PKR) is mediated through NF-kappaB-inducing kinase and ikappaB kinase. Mol. Cell. Biol. 2000, 20, 1278-1290. [CrossRef] [PubMed]

78. Valiente-Echeverria, F.; Melnychuk, L.; Mouland, A.J. Viral modulation of stress granules. Virus Res. 2012, 169, 430-437. [CrossRef] [PubMed]

79. Reineke, L.C.; Lloyd, R.E. Diversion of stress granules and P-bodies during viral infection. Virology 2013, 436, 255-267. [CrossRef] [PubMed]

80. Montero, H.; Trujillo-Alonso, V. Stress granules in the viral replication cycle. Viruses 2011, 3, $2328-2338$. [CrossRef] [PubMed] 
81. Banfield, B.W.; Mouland, A.J.; McCormick, C. 1st international symposium on stress-associated RNA granules in human disease and viral infection. Viruses 2014, 6, 3500-3513. [CrossRef] [PubMed]

82. Ramaswami, M.; Taylor, J.P.; Parker, R. Altered ribostasis: RNA-protein granules in degenerative disorders. Cell 2013, 154, 727-736. [CrossRef] [PubMed]

83. Sephton, C.F.; Yu, G. The function of RNA-binding proteins at the synapse: Implications for neurodegeneration. Cell. Mol. Life Sci. 2015, 72, 3621-3635. [CrossRef] [PubMed]

84. Wolozin, B. Physiological protein aggregation run amuck: Stress granules and the genesis of neurodegenerative disease. Discov. Med. 2014, 17, 47-52. [PubMed]

85. Li, Y.R.; King, O.D.; Shorter, J.; Gitler, A.D. Stress granules as crucibles of ALS pathogenesis. J. Cell Biol. 2013, 201, 361-372. [CrossRef] [PubMed]

86. Li, W.; Li, Y.; Kedersha, N.; Anderson, P.; Emara, M.; Swiderek, K.M.; Moreno, G.T.; Brinton, M.A. Cell proteins TIA-1 and TIAR interact with the $3^{\prime}$ stem-loop of the west Nile virus complementary minus-strand RNA and facilitate virus replication. J. Virol. 2002, 76, 11989-12000. [CrossRef] [PubMed]

87. Dauber, B.; Pelletier, J.; Smiley, J.R. The herpes simplex virus 1 vhs protein enhances translation of viral true late mRNAs and virus production in a cell type-dependent manner. J. Virol. 2011, 85, 5363-5373. [CrossRef] [PubMed]

88. Esclatine, A.; Taddeo, B.; Roizman, B. Herpes simplex virus 1 induces cytoplasmic accumulation of TIA-1/TIAR and both synthesis and cytoplasmic accumulation of tristetraprolin, two cellular proteins that bind and destabilize au-rich RNAs. J. Virol. 2004, 78, 8582-8592. [CrossRef] [PubMed]

89. Finnen, R.L.; Hay, T.J.; Dauber, B.; Smiley, J.R.; Banfield, B.W. The herpes simplex virus 2 virion-associated ribonuclease vhs interferes with stress granule formation. J. Virol. 2014, 88, 12727-12739. [CrossRef] [PubMed]

90. Finnen, R.L.; Pangka, K.R.; Banfield, B.W. Herpes simplex virus 2 infection impacts stress granule accumulation. J. Virol. 2012, 86, 8119-8130. [CrossRef] [PubMed]

91. McEwen, E.; Kedersha, N.; Song, B.; Scheuner, D.; Gilks, N.; Han, A.; Chen, J.J.; Anderson, P.; Kaufman, R.J. Heme-regulated inhibitor kinase-mediated phosphorylation of eukaryotic translation initiation factor 2 inhibits translation, induces stress granule formation, and mediates survival upon arsenite exposure. J. Biol. Chem. 2005, 280, 16925-16933. [CrossRef] [PubMed]

92. Khaperskyy, D.A.; Emara, M.M.; Johnston, B.P.; Anderson, P.; Hatchette, T.F.; McCormick, C. Influenza a virus host shutoff disables antiviral stress-induced translation arrest. PLoS Pathog. 2014, 10, e1004217. [CrossRef] [PubMed]

93. Read, G.S.; Patterson, M. Packaging of the virion host shutoff (vhs) protein of herpes simplex virus: Two forms of the vhs polypeptide are associated with intranuclear B and C capsids, but only one is associated with enveloped virions. J. Virol. 2007, 81, 1148-1161. [CrossRef] [PubMed]

94. Smibert, C.A.; Johnson, D.C.; Smiley, J.R. Identification and characterization of the virion-induced host shutoff product of herpes simplex virus gene UL41. J. Gen. Virol. 1992, 73 Pt 2, 467-470. [CrossRef] [PubMed]

95. Fenwick, M.L.; McMenamin, M.M. Early virion-associated suppression of cellular protein synthesis by herpes simplex virus is accompanied by inactivation of mRNA. J. Gen. Virol. 1984, 65 Pt 7, 1225-1228. [CrossRef] [PubMed]

96. Elgadi, M.M.; Hayes, C.E.; Smiley, J.R. The herpes simplex virus vhs protein induces endoribonucleolytic cleavage of target RNAs in cell extracts. J. Virol. 1999, 73, 7153-7164. [PubMed]

97. Zelus, B.D.; Stewart, R.S.; Ross, J. The virion host shutoff protein of herpes simplex virus type 1: Messenger ribonucleolytic activity in vitro. J. Virol. 1996, 70, 2411-2419. [PubMed]

98. Everly, D.N., Jr.; Feng, P.; Mian, I.S.; Read, G.S. mRNA degradation by the virion host shutoff (vhs) protein of herpes simplex virus: Genetic and biochemical evidence that vhs is a nuclease. J. Virol. 2002, 76, 8560-8571. [CrossRef] [PubMed]

99. Oroskar, A.A.; Read, G.S. Control of mRNA stability by the virion host shutoff function of herpes simplex virus. J. Virol. 1989, 63, 1897-1906. [PubMed]

100. Morse, L.S.; Pereira, L.; Roizman, B.; Schaffer, P.A. Anatomy of herpes simplex virus (hsv) DNA. X. Mapping of viral genes by analysis of polypeptides and functions specified by hsv- $1 \mathrm{x}$ hsv-2 recombinants. J. Virol. 1978, 26, 389-410. [PubMed] 
101. McGeoch, D.J.; Dalrymple, M.A.; Davison, A.J.; Dolan, A.; Frame, M.C.; McNab, D.; Perry, L.J.; Scott, J.E.; Taylor, P. The complete DNA sequence of the long unique region in the genome of herpes simplex virus type 1. J. Gen. Virol. 1988, 69 Pt 7, 1531-1574. [CrossRef] [PubMed]

102. Gaglia, M.M.; Covarrubias, S.; Wong, W.; Glaunsinger, B.A. A common strategy for host RNA degradation by divergent viruses. J. Virol. 2012, 86, 9527-9530. [CrossRef] [PubMed]

103. Abernathy, E.; Glaunsinger, B. Emerging roles for RNA degradation in viral replication and antiviral defense. Virology 2015, 479-480, 600-608. [CrossRef] [PubMed]

104. Doepker, R.C.; Hsu, W.L.; Saffran, H.A.; Smiley, J.R. Herpes simplex virus virion host shutoff protein is stimulated by translation initiation factors eIF4B and eIF4H. J. Virol. 2004, 78, 4684-4699. [CrossRef] [PubMed]

105. Feng, P.; Everly, D.N., Jr.; Read, G.S. mRNA decay during herpes simplex virus (hsv) infections: Protein-protein interactions involving the hsv virion host shutoff protein and translation factors eIF4H and eIF4A. J. Virol. 2005, 79, 9651-9664. [CrossRef] [PubMed]

106. Dauber, B.; Saffran, H.A.; Smiley, J.R. The herpes simplex virus 1 virion host shutoff protein enhances translation of viral late mRNAs by preventing mRNA overload. J. Virol. 2014, 88, 9624-9632. [CrossRef] [PubMed]

107. Kedersha, N.; Anderson, P. Regulation of translation by stress granules and processing bodies. Prog. Mol. Biol. Transl. Sci. 2009, 90, 155-185. [PubMed]

108. Finnen, R.L.; Banfield, B.W. Endoribonuclease deficient virion host shutoff protein of herpes simplex virus type 2 localizes to stress granules. 2016. (unpublished; manuscript in preparation).

109. Kedersha, N.; Stoecklin, G.; Ayodele, M.; Yacono, P.; Lykke-Andersen, J.; Fritzler, M.J.; Scheuner, D.; Kaufman, R.J.; Golan, D.E.; Anderson, P. Stress granules and processing bodies are dynamically linked sites of mRNP remodeling. J. Cell Biol. 2005, 169, 871-884. [CrossRef] [PubMed]

110. Everly, D.N., Jr.; Read, G.S. Site-directed mutagenesis of the virion host shutoff gene (UL41) of herpes simplex virus (hsv): Analysis of functional differences between hsv type 1 (hsv-1) and hsv-2 alleles. J. Virol. 1999, 73, 9117-9129. [PubMed]

111. Page, H.G.; Read, G.S. The virion host shutoff endonuclease (UL41) of herpes simplex virus interacts with the cellular cap-binding complex eIF4F. J. Virol. 2010, 84, 6886-6890. [CrossRef] [PubMed]

112. Glaunsinger, B.; Ganem, D. Lytic KSHV infection inhibits host gene expression by accelerating global mRNA turnover. Mol. Cell 2004, 13, 713-723. [CrossRef]

113. Glaunsinger, B.; Chavez, L.; Ganem, D. The exonuclease and host shutoff functions of the SOX protein of kaposi's sarcoma-associated herpesvirus are genetically separable. J. Virol. 2005, 79, 7396-7401. [CrossRef] [PubMed]

114. Covarrubias, S.; Richner, J.M.; Clyde, K.; Lee, Y.J.; Glaunsinger, B.A. Host shutoff is a conserved phenotype of gammaherpesvirus infection and is orchestrated exclusively from the cytoplasm. J. Virol. 2009, 83, 9554-9566. [CrossRef] [PubMed]

115. Rowe, M.; Glaunsinger, B.; van Leeuwen, D.; Zuo, J.; Sweetman, D.; Ganem, D.; Middeldorp, J.; Wiertz, E.J.; Ressing, M.E. Host shutoff during productive epstein-barr virus infection is mediated by BGLF5 and may contribute to immune evasion. Proc. Natl. Acad. Sci. USA 2007, 104, 3366-3371. [CrossRef] [PubMed]

116. Khaperskyy, D.A.; McCormick, C. Timing is everything: Coordinated control of host shutoff by influenza a virus NS1 and PA-X proteins. J. Virol. 2015, 89, 6528-6531. [CrossRef] [PubMed]

(C) 2016 by the authors; licensee MDPI, Basel, Switzerland. This article is an open access article distributed under the terms and conditions of the Creative Commons by Attribution (CC-BY) license (http://creativecommons.org/licenses/by/4.0/). 